\title{
TARRA BOBBY, A BRATAUALUNG MAN
}

\author{
Bain Attwood
}

In the last decade biographical writings have provided much-needed Aboriginal accounts of the history of their interaction with Europeans in Australia. Nearly all of these life histories have been oral-based, transmitted by their subjects or by others who have known them. ${ }^{1}$ It has been much more difficult to provide voices for individual Aboriginal men and women who lived in the nineteenth century, but several recent essays have shown that it is possible to provide from the documentary record some indications of the perspectives of this historically inarticulate group. ${ }^{2}$

In the case of Tarra Bobby, he left no written sources for he was illiterate, but a scouring of the correspondence of missionaries and government officials, the reporting of provincial and metropolitan newspapers, and the writings of ethnographers provides some of the pieces from which Tarra Bobby's life can be reconstructed. The record is, nonetheless, undeniably patchy, and so I have adopted two approaches: firstly, where I have been unable to learn anything directly because the sources are simply not extant, I have described the wider social context in which he lived (this method seems sensible for the 'individual' and 'society' are not mutually exclusive entities, especially in traditional Aboriginal societies where the notion of a discrete individual personality is particularly problematic); and secondly, where the evidence is much fuller, I have dwelt on particular incidents in Bobby's life, using these as a window through which we might look upon some of the main strands of his life history.

Tarra Bobby was probably born in the late 1830 s or early 1840 s, to the Brataualung clan, (part of a wider regional grouping known as the Kurnai), which claimed the country from Cape Liptrap west of Wilsons Promontory and east of the Tarwin River, to the mouth of Merrimans Creek and inland towards the south bank of the La Trobe River. He seems to have been a member of a residential group (or band), the Yauung, which was centred on Warrigal Creek and the Tarra River $^{3}$ (named after an Aboriginal guide, Charley Tarra, who accompanied the Polish explorer Count Paul de Strzelecki into the area in 1840 as well as a pastoral company established the following year). While Bobby would have been given an Aboriginal name at birth, and acquired another at initiation, he was generally known to European settlers and among Aborigines by his European name; he probably became known as 'Tarra Bobby' because Europeans wanted to distinguish him from two fellow tribesmen

Bain Attwood teaches history at Monash University and is the author of The making of the Aborigines, to be published mid-1989.

1 Beckett 1978; Kennedy 1985; Mathews 1977; Roughsey 1971; Roughsey 1984; Shaw 1981, 1983 , 1986; Tucker 1975; West 1984; White, Barwick and Meehan 1985.

2 Attwood 1986; Aveling 1985; Barwick 1985; Pedersen 1984; Penny 1985.

3 Notes (Howitt Papers (a), 1053/4a); Fison and Howitt 1880:228; Howitt 1904:77; Tindale 1974:203. 
who had been given or taken the same name, while such a connection with the physical world was consonant with traditional Aboriginal culture. ${ }^{4}$

The Brataualung had established some sort of modus vivendi with European pastoralists soon after their intrusion onto their tribal land in 1841 . While they had been initially suspicious and watchful, they soon initiated contact with these whites, and friendly relations were eventually forged between them. ${ }^{5}$ It seems that the Brataualung had had some earlier relations with Europeans - sealers and whalers who had based themselves around Wilsons Promontory and Corner Inlet in the 1820s and 1830s - and when the pastoralists came they may have believed their presence would also be only small-scale and seasonal. However, a small town soon grew up which became Port Albert, and several runs were established nearby. Yet the Brataualung, instead of attempting to drive the Europeans off their land, began working for the settlers in return for food and other goods. They attempted to incorporate the newcomers into their kin-based society by sharing their knowledge of the land, exchanging names, and providing sexual companionship. ${ }^{6}$ These relatively harmonious relations lasted until July 1843 when several white men - perhaps runaway Vandemonian convicts living on the beach at Port Albert and trading illegally in grog - killed some Brataualung men who, in turn, chose to kill 'one big fellow white man', a leading stockholder in the district, in an attempt to restore the status quo upset by these deaths. The squatters responded by mounting a brutal reprisal raid which caused considerable loss of Brataualung life, and the amicable relations in the area broke down completely; the Aborigines moved away from the Port and its surrounding runs, and avoided any further contact with whites for several years. ${ }^{7}$

After withdrawing from white settlement in 1843, however, the Brataualung found it difficult to survive: the loss of access to indigenous food sources and the ravages of Europeanintroduced diseases took a heavy toll; by 1848 they numbered less than fifty and were reportedly in 'a very unhealthy state', suffering from respiratory problems, influenza and malnutrition. Mainly as a result of their impoverished and weakened condition, but also because they were attracted to some aspects of white society, particularly its material goods, they started to move in to European settlement, initially camping at two stations on Merrimans Creek, Coady Vale and Erin Vale, as well as on smaller stations around Port Albert. Later they moved hesitantly into the tiny settlements of Tarraville, Victoria and Alberton which lay within three or four miles of one another. Ranging more freely once again over their tribal land, they found a much-changed world and soon learned that to survive they had to adapt to the colonists on terms not of their own making. ${ }^{8}$

4 Port Phillip Herald, 9 June 1840; Smyth 1878:xxi-xxii, 94; Brodribb 1978:28.

5 Port Phillip Patriot, 21 January, 4 February, 22 March 1841; Port Phillip Herald, 23 March 1841; Brodribb 1978:30-32.

6 Port Phillip Patriot, 6 May, 10 June 1841, 15, 29 August 1842; Committee on Immigration 1842:53; Port Phillip Herald, 19 May 1843; Charles J. Tyers to Superintendent, Port Phillip, 1 February 1845, 45/324 (Public Record Office (PROVic), Series 19); Bride 1969:243.

7 Robinson Journal, 8, 25 June 1844; Select Committee 1845:45; Mackaness 1941:10; Gippsland Standard, 25 September 1912.

8 Tyers to Superintendent, Port Phillip, 29 December 1849 (New Sou th Wales Archives Office (NSWAO), Series 4/1141.2; Tyers to Superintendent, Port Phillip, 7 March 1851, (Tyers Diaries); Aborigines, return to an address 1853:19-21; King Daybooks, 6 February 1849. 


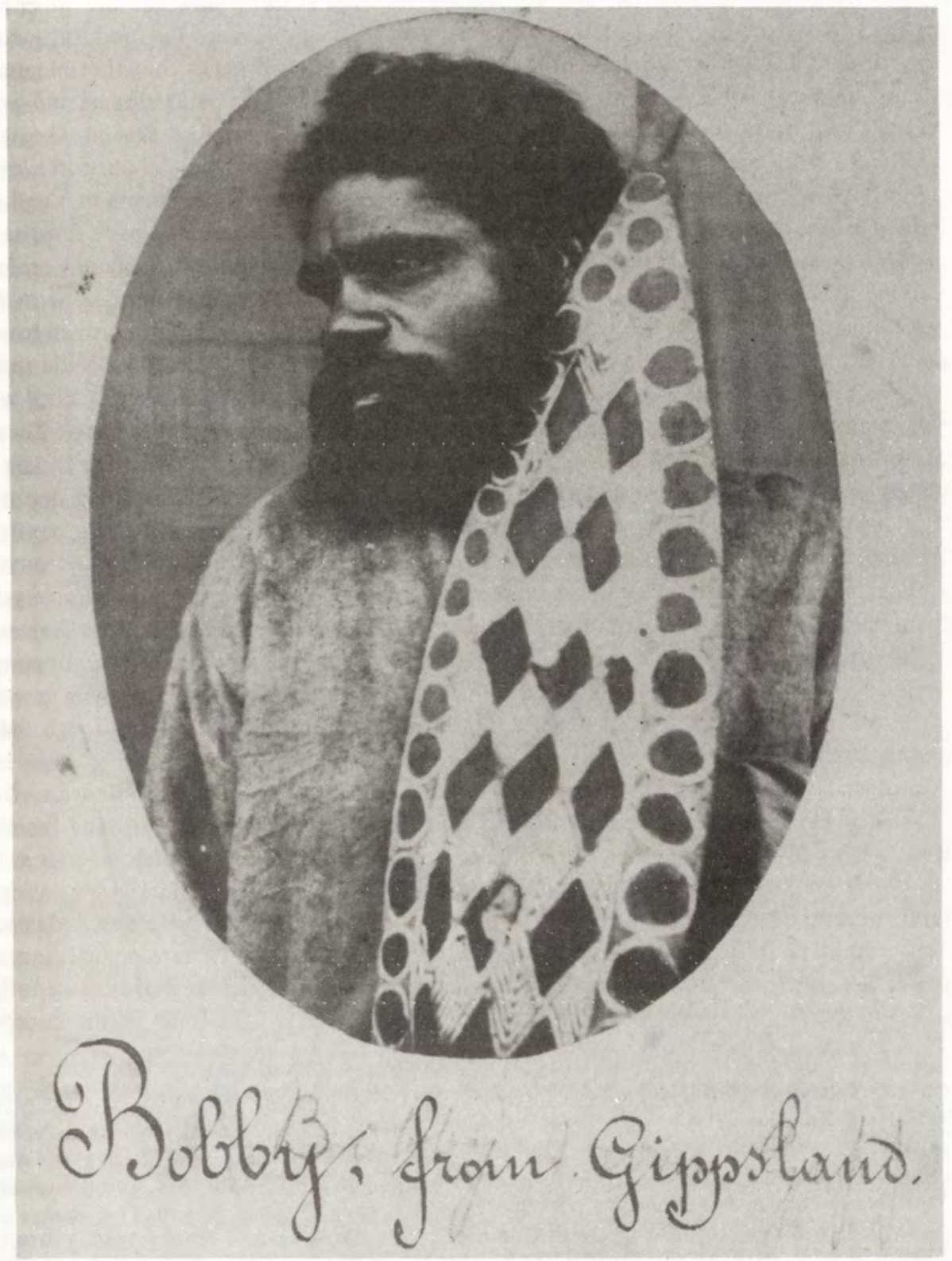

Tarra Bobby left no written records; this portrait might be said to be the only document in which he speaks directly to us. Even though it is an image produced by a professional photographer, Charles Walters, and tells us as much about the way he and some other Europeans saw Aborigines in Victoria in the mid-19th century, it nonetheless serves to counteract the view of Bobby encoded in the writings of missionaries and government bureaucrats: of an inveterate and weak-minded drunkard, a nomadic and immoral troublemaker, adrift between two cultures. Here he appears in European garb but his bearing and the shield convey a sense of purpose and dignity rooted in his own culture. In most of the other sensitively-tendered portraits in the album in which this photo appears, the subjects are not accompanied by the symbols of traditional Aboriginal culture. Perhaps this suggests that either Bobby chose to be photographed in this way or that Walters realised it was appropriate for him to be portrayed like this. Photo: C.W. Walters, courtesy of the Museum of Victoria. 
As they moved onto pastoral runs some squatters, realising they now had the upper hand, demanded that the Aboriginal men undertake small jobs in exchange for food, tobacco and tea. At Coady Vale pastoralist Patrick Coady Buckley soon grasped that the Brataualung could be used for other work, and began employing the men as barkstrippers and potato harvesters. At Tarraville another settler James McAlpine also engaged several Aborigines, including Tarra Bobby, for different tasks. When almost all of the white labour force left for the goldfields in the summer of 1851-52, Aborigines were employed as stockmen, shepherds, sheepwashers and reapers in the district, winning praise from settlers who were surprised by their willingness and ability to do such work. ${ }^{9}$ The Brataualung, however, generally preferred to survive by other means and continued to gather traditional foods where these were available, supplementing them by begging money and food at the stations and in the small towns.

In this context of social and cultural upheaval, Tarra Bobby could hardly be said to have been born into traditional Kurnai society, but nonetheless he grew up in an Aboriginal world which retained considerable strength and vitality in the midst of enormous change. The Brataualung maintained strong links with their tribal land, and upheld customary beliefs and practices. Two clan headmen, known as Old Morgan and Old Darby, assumed important roles in Bobby's early years, imparting tribal knowledge and laws, and exercising considerable influence over him and other young Brataualung men. In the early 1850 s they convened an elaborate initiation ceremony in which Bobby and some other Kurnai boys became young men and were given new names, their childhood names becoming seciet ones. Sometime later Bobby was chosen for the important tribal position of messenger (lewin or paiara), whereby he was entrusted to communicate important messages to the Brataualung as well as to other Kurnai clans, calling them to ceremonies or to resolve disputes through formal mechanisms. ${ }^{10}$

Although he grew up in this traditionally-oriented milieu, Bobby was also drawn to European society. He became part of a small cross-clan group of young Brataulung and Braiakaulung men who developed a feeling of comradeship among themselves wiich was not as narrowly based on kinship and territory as such bonds were formerly. These youths adopted European dress, developed a strong taste for alcohol, tobacco and smart clothes, and became fervent gamblers and sharp card players. In the late 1850 s they moved about together between Sale, the other small towns and the stations in the district, as vell as going to Melbourne on several occasions. ${ }^{11}$ While they became well known to some of the European

9 Tyers to Superintendent, Port Phillip, 23 January 1851, 7, 3 February 1851, 3 February 1852; Tyers to Colonial Secretary, 15 January 1853, 9 February 1854 (Tyers Diaries); King Daybook, 2 December 1854, March and April 1855; Buckley Journal, 21 October 1849, 25 February-? March 1850, August 1852, 26-21 October, 1 November 1853, 19 April-6 May 1854, 8-15 April 18j4, 4 September 1856; Aborigines, return to an address 1853:18-21; Thomas, Journal of Gippsland viit, 31 December 1860 (Thomas Papers, Item 16); Thomas to President of Lands and Works, 2 Februiry 1859, A1859/642, 9 February 1859, B1859/707, 19 April 1859, A1859/2089, 14 September 1859, A1859/4968 (PROVic, Series 2896); Notes (Howitt Papers (a), 1053/4a).

10 Notes (Howitt Papers(a), 1053/3a), 1053/4a); Fison and Howitt 1880:191, 193, 199, 210, 230, 251-53; Bulmer to Howitt, 15 April 1880 (Howitt Papers (b), Box 1; Folder 6); Howitt 1886:413-14, 1887:passim, 1904:617-18; Smy th 1878:40.

11 Thomas Journal, 21 October 1857 (Thomas Papers, Item 4); Gippsland Guarditn, 3 September 1858; Thomas to President of Lands and Works, 13 September 1858, C1858/47£0, 18 October 1858, C1858/5425, 15 February 1860, A1860/761, 22 February 1860, B1860/3817, 28 February 1860, A1860/1007 (PROVic, Series 2896); Select Committee 1858-59:58. 
settlers, such as Angus McMillan on Bushy Park station, their presence and particularly their heavy drinking in camps on the fringes of the townships often caused alarm and fear, and brought complaints about drunkenness and their harassment of passers-by for food, tobacco, grog and money. ${ }^{12}$

The most serious incident of this kind was in Sale township late one evening in August 1858 when Tarra Bobby and another Aboriginal man, Billy Login, accosted a similarly drunk man, a local white resident Richard Dothwaite, for money; he angrily refused and lurched at Billy. In the struggle which followed both Aboriginal men struck Dothwaite down with sticks and robbed him. ${ }^{13}$

Dothwaite was found dead the following morning and the Aborigines quickly decamped when they realised what had happened. They were rounded up later by the police and local settlers and brought before an inquest conducted by the local coroner, Dr Alexander Arbuckle. While he was well known to these men, (having provided them with medical care over several years), and McMillan acted as interpreter, Bobby and Login were confused by the proceedings and accused one another of striking Dothwaite. The jury decided that Dothwaite had died as a result of blows to his head, but ruled there was insufficient evidence to conclude who had inflicted them. Subsequently, however, further police questioning adduced more evidence, and Bobby and Login were committed to stand trial for murder at the Melbourne Criminal Court the following month. Together with another Aboriginal man, Jemmie Scott (who was to act as witness), they were given into McMillan's custody, to be taken by steamer from Port Albert to Melbourne; on their arrival there on 11 September they were taken to Pentridge Gaol. ${ }^{14}$

For Tarra Bobby and Billy Login, Dothwaite's death, their arrest and subsequent detention were undeniably traumatic, the more so because they would have recalled or known of the brutal reprisals which had followed previous Aboriginal killings of whites. Their anxiety worsened as they left their kin and country, and were transferred to the strange surroundings of a large prison within Bunurong territory. While relationships between the Kurnai and their former clan enemies had improved since the late 1840s Tarra Bobby and Billy Login might nonetheless have felt uneasy. The only source of comfort came in the familiar face of William Thomas, the Guardian of Aborigines, whom they had met the previous year in Melbourne.

He acted as a solicitous protector, acquainting himself with the case, securing legal counsel for them and briefing the lawyer on several occasions. Throughout their lengthy detention he visited them almost daily, taking them food and speaking to them for hours at a time, explaining 'white man's laws when they find any killed', and lecturing them on the 'crime of drunkenness', telling them it had brought them to gaol. On one occasion, Billy or Login parried 'what for white man bring us rum?' On Sundays Thomas preached on 'the evil of sin', and he and a young Aboriginal convert sang hymns to them. Much of the time the two men were 'very low spirited' and 'very dull', but they apparently brightened up at seeing the Guardian, and while they were less pleased when he scolded them they nevertheless came to depend upon his attention and repeatedly urged him 'to come tomorrow'; he was at

12 Harrison n.d.; Leslie and Cowie 1973:29; Gippsland Guardian, 7 August 1857; Select Committee 1858-59:33, 75 .

13 For a discussion of other aspects of this incident and the trial see Attwood, for thcoming, Chapter 5.

14 Gippsland Guardian, 3, 17 September 1858; Regina vs Tarra Bobby and Billy Login, (PROVic, Series 30, Unit 219, File NCR 2370). 
least 'a friend', somebody in an alien environment who could provide some reassurance and partial relief from the stultifying boredom of their prison cell. Their trial was repeatedly postponed as all the witnesses failed to appear and each time, after having been taken to court, instructed by Thomas on how to behave in the dock and been attired in new clothes to 'appear respectable', Tarra Bobby and Billy Login were returned to Pentridge.

With each delay, they grew more anxious, becoming particularly distressed when some fellow prisoners convicted of capital offences were executed at Pentridge. Billy Login was so terrified Thomas 'could scarcely pacify him', and the Guardian actually only made matters worse by taking 'the advantage to press the equity of our laws against one taking the life of another'. As the day of their deferred trial drew nearer in mid-November, both men became extremely uneasy and afraid. On the sixteenth and seventeenth of that month they were taken to the Court, but their trial did not come up, and it was the nineteenth before they were finally placed in the dock, only to be discharged by the judge and placed in Thomas's care. (In the absence of prosecution witnesses the case could not be tried, as English law prohibited accused persons from testifying.) Bobby and Billy Login, relieved and scarcely believing their good fortune, went with Thomas to his residence where they were given food and shelter for the night. The following morning before the sun had barely risen, they were ready to leave and by 7.00 they set off for their own country after thanking Thomas profusely. 15

On their return, they found their kinsmen and some local whites intent on finding a way to alleviate the condition of Aborigines in the area. The Brataualung and most of the other blacks were more than ever now remnant populations, struggling to eke out a meagre existence on the fringes of European society. The Brataualung repeatedly told a doctor in Tarraville, Mr G.D. Hedley, that they wanted 'a spot which they could call their own' - a reserve. In April 1859, perhaps on Bobby's initiative, a small group of Kurnai men travelled to Melbourne to call on Thomas, having heard that the Woiworung, the Taungurong and the Ngurai-illam-wurrung clans had secured a reserve in the Upper Goulburn area on the Acheron River. Simon Wonga, a ngurungaeta or leader of the Wurundjeri-balluk clan of the Woiworung, introduced them to the Guardian but he suggested they return to Gippsland and talk to some of the local pastoralists. They did so but three months later returned to see Thomas again, impatient with the inactivity of local white settlers and the government. ${ }^{16}$ Their interest in obtaining reserves was fuelled further by Tarra Bobby, but not before the young Brataualung man had tangled again with the law.

In February 1860, he, Billy Login and a few other Aboriginal men set off for Melbourne, stopping at the Anderson's Creek gold diggings. There they seem to have fallen foul of a European man, (perhaps because they might have harassed him for food and money), and he fired upon them; the trigger-happy digger was charged with assault and fined $£ 5$, and the

15 Thomas to Surveyor General, 10 January 1859 (Thomas Papers, Item 7); Thomas to President of Lands and Works, 13 September 1858, C1858/4780, 21 September 1858, C1858/5404, 29 September $1858, \mathrm{D} 1858 / 5134,18$ October $1858, \mathrm{D} 1858 / 5425,26$ October $1858, \mathrm{C} 1858 / 5596,2$ November 1858, D1858/742, 10 November 1858, D1858/5979, 17 November 1858, C1858/6206 (PROVic, Series 2896).

16 Thomas to President of Lands and Works, 21 September 1858, C1858/5045, 19 April 1859, A1859/ 2089, 14 June 1859, B1859/3170 (PROVic, Series 2896); Thomas Journal, 13 April, 5 June 1859, Journal of Gippsland Visit, 31 December 1860 (Thomas Papers, Items 4, 16). 
money was handed over to Bobby and Login, but the former had received a severe eye injury. They travelled to Melbourne where Thomas took him to hospital; Bobby was reluctant to remain as, like other Aborigines, he associated illness with locality. After being operated upon he was ordered to rest for two weeks and was persuaded to stay by Thomas who visited him frequently. ${ }^{17}$

When he was discharged from hospital, Bobby travelled to the Aboriginal Reserve on the Acheron River where he found many Aborigines busily working the land 'like white man' under the guidance of a teacher, Robert Hickson. ${ }^{18} \mathrm{He}$ was most excited by what he saw, and on his return to Melbourne gave Thomas 'a glowing account of blacks working hard, making Paddocks \&c. \&c.', telling him 'blackfellows Gippsland by and by like that'. (Within months, the Aborigines encountered settler opposition and were shifted in September 1860 against their wishes to another site, Mohican Station.) Much of Bobby's buoyant optimism was due to the fact that the Taungurong had bestowed a young woman, Annie, upon him in accordance with the practice of exchanging women between distant clans. ${ }^{19}$ In the Brataualung and other Kurnai tribal groups there were few young women available as partners for men because the customary marriage laws required men and women to marry exogamously and men far outnumbered women in the small population. ${ }^{20}$ By this marriage, Bobby may have assumed certain responsibilities within the Taungurong clan and soon after, perhaps acting in the formal capacity of a messenger, he travelled to Gippsland to carry news about the Acheron Reserve. In June many Kurnai - reportedly about a hundred - went there to see the new reserve. ${ }^{21}$

On his return to Gippsland, Bobby spent some time working as a reaper, earning 'plenty of money', and early in 1861 he returned to Melbourne where he spent his wages freely on clothes and drank heavily. Thomas scolded him for drinking and his 'wandering', telling him to stay with his wife and new-born child; Bobby responded by asking for money for a fare on the steamer so he could repeat the journey he and Billy Login had first made in September 1858 when they were escorted to Melbourne to stand trial, but Thomas refused, and Bobby had to go on foot. ${ }^{22}$

In July 1862 he returned to Melbourne with other Kurnai tribesmen and they waited on Thomas, complaining they had not been supplied with food or blankets by the Central Board for the Protection of Aborigines, and asking him to secure the release of a kinsman serving a sentence in Pentridge Gaol. The Guardian angrily told them they should 'stop in their own country' and cursed the newly-founded Central Board for the Protection of the Aborigines for not ensuring this. But they stayed and, with other Aborigines, drank heavily. In mid-August, Bobby fell ill and was taken to hospital in a drunken stupor. Once more Thomas visited him, attempting 'to impress upon his mind about drink', and after a spell in

17 Thomas Journal, February 1860, Depositions Notebook, 1860, (Thomas Papers, Item 5).

18 Thomas to Secretary, CBPA, 26 July 1860 (Australian Archives (AA) Brighton, Series B312, Item 3).

19 Thomas to President of Lands and Works, 11 April 1860, B1860/1862 (PROVic, Series 2896).

20 Thomas, Journal of Gippsland visit, 31 December 1860 (Thomas Papers, Item 16); Return on tribes, numbers, and sex of Aborigines in Gippsland, 20 July 1863 (AA Brighton, Series B312, Item 9).

21 Gippsland Guardian, 29 June 1860.

22 Thomas Journal, 3 January 1861, Report, 1 January 1861-June 1862 (Thomas Papers, Items 5, 7). 
hospital Bobby was discharged into Thomas's care and put on the road to Gippsland ${ }^{23}$ By January 1863, however, he was back in Melbourne again, this time with Billy Login, and once more they were 'in trouble', with Login being gaoled for a short period. (Thomas aptly described them as 'companions in tribulation'.) He provided them with food, tobacco and tea and packed them off to Gippsland before they could run foul of the law again. ${ }^{24}$

Back in Gippsland, relations between Aborigines and Europeans were beginning to undergo a fundamental change through the coming of Christian missionaries into the area. Some of the Brataualung met one of them, Friedrich Hagenauer, in May 1861 at Tarraville, as the Moravian missionary made an investigatory journey through south-western and central Gippsland, but 'Old Morgan' was the only one to express any interest in Hagenauer's mission which he hoped to found at Bushy Park. Hagenauer may have endeared himself to 'Old Morgan' by giving him a few small presents. They renewed their acquaintance the following February when Hagenauer returned to Gippsland to start his mission, and once more later in 1862 when he visited Port Albert again and urged the Brataualung to return with him. While a small block of land had been set aside near Alberton, there was little likelihood of the Aborigines occupying it, but they were reluctant to move away from their tribal land to where Hagenauer himself was seeking land for a mission station in the face of government and some local opposition.

In the meantime, 'Old Morgan' became more perturbed about the future of his young kinsmen, and particularly their liking of alcohol, and it would seem he came to regard the missionary as someone who could play a role similar to his own as tribal headman. In May 1863, the old man travelled to Sale to see the missionary and, again moved by Hagenauer's purpose and kindly manner, he resolved to seek out some of the young men; he talked to them late into the night, urging them to go to the missionaries. The following morning several of them arrived at the Hagenauer's house, telling him 'Old Morgan' had sent them. The following month the Hagenauers and a large group of Aborigines, including a few Brataualung men, moved to a site on Lake Wellington where they had been granted land. Later, 'Old Morgan' himself went to this new station, Ramahyuck, (where he died in December 1864). ${ }^{25}$

Some of the Brataualung, however, preferred to stay in their own tribal country or at least were reluctant to move onto Brabiralung land where Ramahyuck lay. Tarra Bobby, Annie, and another Brataualung man, Bobby Coleman, chose in the winter of 1863 to go to another newly-founded station, Coranderrk, near Healesville. It had been reserved in June after John Green, a missionary layman who had replaced Hickson at the much-disliked Mohican Reserve in March 1862, and forty Woiworung Aborigines had abandoned Mohican and chosen a site at the junction of Badger Creek and the Yarra where they were later joined by the Taungurong. ${ }^{26}$ The Woiworung and Taungurong were eager to live in a European manner, many converted to Christianity, and the work of developing the land was under-

23 Thomas Journal, 11, 18 July, 11, 17 August, 8 September 1862 (Thomas Papers, Item 5); Hagenauer to Reichel, 19 May 1862 (Moravian Mission, MF 166).

24 Thomas Journal, 30 January, 1 February 1863 (Thomas Papers, Item 5).

25 Hagenauer to Reichel, 10 September 1861, 17 February, 17 March, 19 May 1862, 19 June 1863, Hagenauer, Report of missionary tour through Gippsland in July and August I861 Moravian Mission, MF 166).

26 CBPA, 1st Report 1861:4-5; John Green to Secretary, CBPA, 28 July 1863 (AA Brighton, Series B312, Item 9). :. 
TARRA BOBBY, A BRATAUALUNG MAN

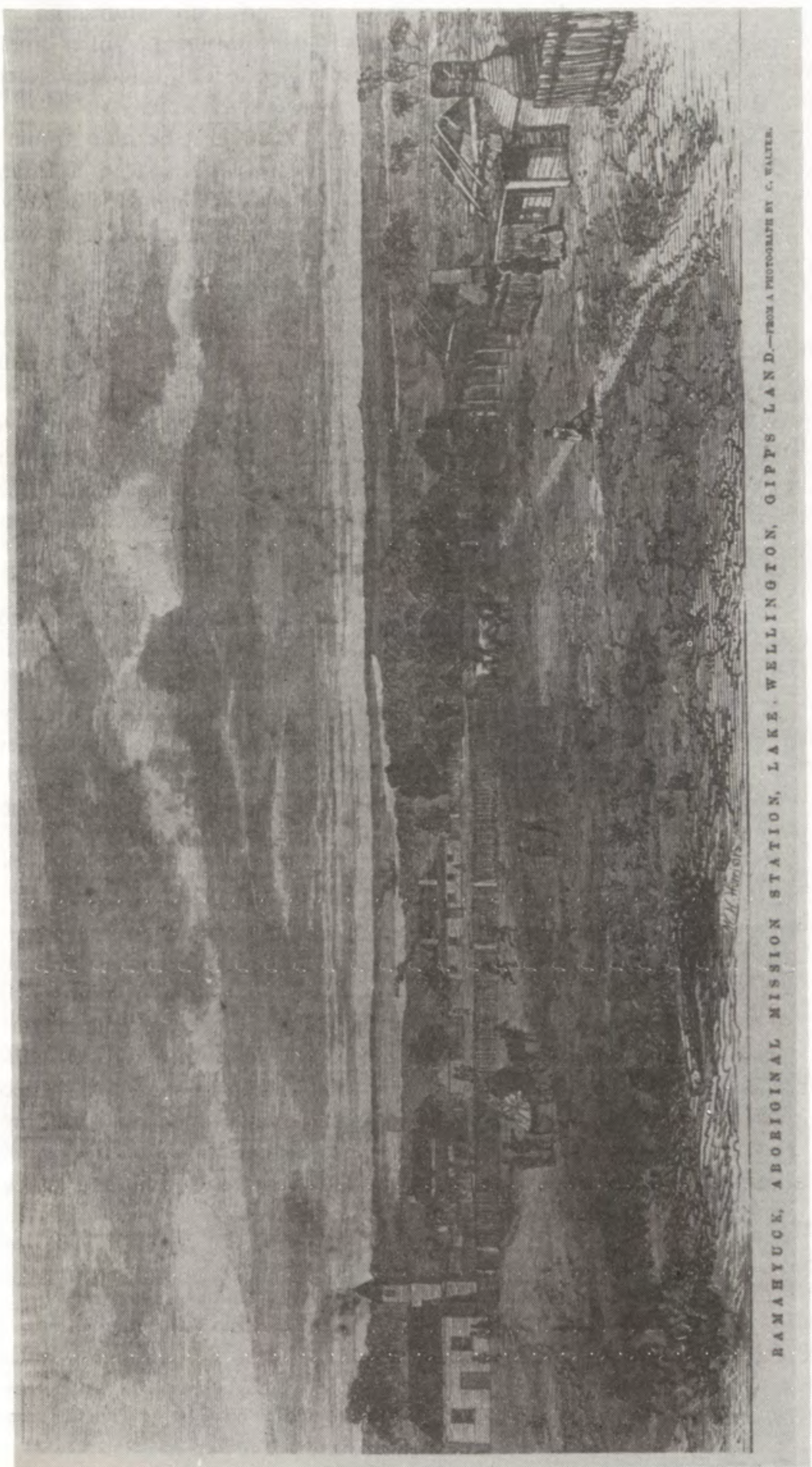

झ

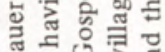

施

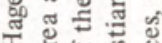

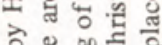

ठิษ ฮี

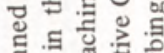

\&苋㲾

잉

突产

สำ

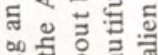

잉ํํ ส

몽

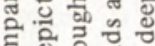

응혀년

원돌

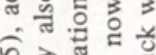

ณ. 预

خ잃요

สิ

है

드는 을

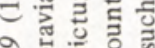

๖े

告它

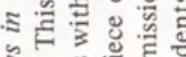

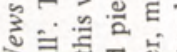

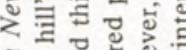

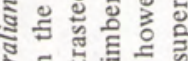

ถิ

ฟ

ป

홀을

气

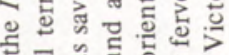

ฮี

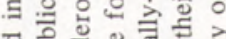

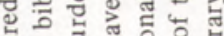

ษ

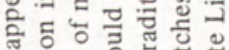

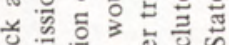

हี 壱苛

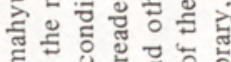

สี ฮู ญ

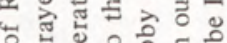

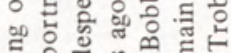

절

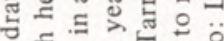

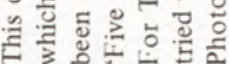


taken energetically and with a speed the Central Board considered 'truly astonishing'. ${ }^{27}$ They identified closely with the place they had chosen and were optimistic about their future there, regarding John Green with ever-increasing respect and affection, and responded to a style of management which allowed them 'to rule themselves as much as possible'. ${ }^{28}$

It is unclear why Tarra Bobby decided to go to Coranderrk; it could have been on Annie's initiative, the result of her wanting to live among her own people, but as I can learn nothing about her I can only speculate and she must remain a shadowy part of Bobby's life history. While Bobby was probably as impressed by the early development of Coranderrk as he was by that at Acheron, and built a hut there, he was not to become one of its pioneers. He had only limited tribal standing among the Woiworung as by convention only individuals born on Kulin land could acquire clan membership and 'speak' for their land. ${ }^{29}$ Like many traditionalists, he had little interest in (and was actually distrustful of) the missionaries and their religious faith and, despite prolonged periods of residence on Coranderrk, he continued to regard it or any other mission station as an alien environment. He continued to draw much of his sense of purpose and confidence from a traditionally-oriented Aboriginal world rather than one influenced by missionaries and other Europeans. His authority lay among the Brataualung and it was to his own country and kin that he was repeatedly drawn, as well as to Thomas in Melbourne.

In the mid-1860s Bobby was 'often on the road' between Ramahyuck and Coranderrk, acting the role of messenger and mediator in an attempt to persuade more Kurnai men to go and settle at the Healesville station where there was more prospect of finding marital partners. In doing this, Bobby caused considerable disruption on the mission station, especially in May 1866 when he persuaded about twenty-five to leave including some who had already made a commitment to Ramahyuck by building small cottages, and one who was under special religious instruction. This enraged Hagenauer and forced him to move quickly to obtain some young women from Western Australia in order to 'settle' the men down. ${ }^{30}$ The two men clashed again in an inter-tribal dispute in Gippsland which came to a head in 1868; the previous August, a Kurnai man had died in Sale, and some of his kinsmen had suspected sorcery and planned a revenge party upon the assumed perpetrators, the Brataualung, Braiakaulung and Brabiralung, who were on Ramahyuck. Hagenauer, however, had intervened to prevent this, but several months later some traditionalists decided to resolve the dispute and called on Aboriginal men on Ramahyuck and Lake Tyers Mission Stations to meet at Lake Victoria for a formal, staged 'fight'. It seems many of them were only reluctant participants, and when Hagenauer and the local police intervened they returned to Ramahyuck with him. Tarra Bobby, however, was extremely annoyed by the missionary and police action which had prevented him and a few other traditionally-oriented men from settling the dispute. Bobby told the policeman he would go and see Robert Brough Smyth, the secretary of the Central Board for the Protection of the Aborigines, in Melbourne and lay a

27 Barwick 1968:10-13.

28 Barwick 1968:14; Green to Secretary, CBPA, 28 July 1863 (AA Brighton, Series B312, Item 9).

29 CBPA, 5 th Report 1866:5; Barwick 1984:106, 107, 113-14.

30 Hagenauer to Rev. A.J. Campbell, 24 May 1866, Hagenauer to Robert Brough Smyth, 25 September 1868 (Hagenauer 1865-72); CBPA, 6th Report 1869:23; Thomas Journal 1867 (Thomas Papers, Item $5)$. 
complaint agannst Hagencuer and the police who had interfered with the arrangements of the Blacks who had a perfect right to do as they pleased'. 31

Bobby presumably returned to Coranderrk, but it is unlikely he stayed for long; some evidence suggests that he was on poor terms with many of the Aborigines there as well as Green. A clergyman familiar with Coranderrk, Rev. Robert Hamilton, claimed that Bobby's conduct was 'as a general rule . . . intolerable' as he was 'an inveterate drunkard and a perfect moral plague'. His drunkenness and 'disorderly and riotous conduct' may have led to repeated expulsions from the station. ${ }^{32}$ And when Thomas died in 1867 , Bobby lost a kindly benefactor and a convenient place of refuge, both of which had been an important focus of his life for almost a decade. He also increasingly felt he had been abandoned by his kin who had either died or adopted a lifestyle alien to him. Although he continued to be drawn to his own country, by the late 1860 s the few remaining Brataualung were no longer living on their traditional land, while Billy Login, for example, had 'settled down' on Ramahyuck and been converted by the missionaries. In the early 1870 s, Bobby's sense of isolation was compounded when Annie seems to have died. Throughout this time, Bobby's health continued to deteriorate, and he was forced to spend periods in hospital in Melbourne. ${ }^{33}$

In the context of a growing determination of the Board and missionaries to enforce a policy of segregating Aborigines on reserves, Bobby's poor health and his lack of either European protectors or an extended kin network left him extremely vulnerable. His peripatetic movement between Coranderrk, Melbourne and Gippsland became increasingly unacceptable to Brough Smyth and the missionary managers for whom he was the antithesis of their ideal - they saw him as a wanderer and a drunkard, dissolute, lazy and heathen. But so long as they disagreed as to who should take responsibility for him, Tarra Bobby could evade their paternalistic rule.

Green saw little point in Tarra Bobby being sent to Coranderrk for he would not 'settle there', while Brough Smyth who claimed to be 'well acquainted' with Tarra Bobby saw little point in sending him to Ramahyuck because he was 'not quite right in his mind' and he always found 'his way back to Melbourne', and the autocratic secretary reserved the right to decide where he should go. ${ }^{34}$ Hagenauer was also unhappy with the prospect of Tarra Bobby being on Ramahyuck, especially after an abortive mission to Port Albert in the spring of 1872 to persuade Tarra Bobby to go on to Ramahyuck. Bobby had eluded him and the local Police Magistrate (who had earlier detained him on a charge of vagrancy), and escaped back to Melbourne, prompting the Police Magistrate to remark to Hagenauer 'There you are, we're done'. 35 .

In early 1873 Bobby grew impatient at the Board's refusal to allow him to leave Coranderrk. He walked off the station late one night, travelling about fifteen miles before two men sent by Green caught up with him; he refused to return to Coranderrk with them but they

31 Hagenauer to Brough Smyth, 25 September 1868 (Hagenauer 1865-72).

32 Argus, 24 April 1874.

33 Thomas Journal, 5 December 1864, January, June 1865, June 1867; CBPA, 5th Report 1866; Gippsland Mercury, 27 April 1874; Gippsland Times, 28 April 1874.

34 John Green to Secretary, BPA, 23, 26 February 1873 (AA Brighton, Series B313, Item 163); BPA, Minutes, 7 March 1873 (AA Brighton, Series B314, Item 3).

35 Gippsland Mercury, 27 April 1874; Gippsland Times, 28 April 1874. 
got the police at Lilydale to take him into their charge. The next morning a buggy was sent from Coranderrk and Bobby returned ignominiously to the station. The following month the Board, ignoring Smyth's counsel, decided Bobby could go to Ramahyuck on the condition he stay there. A week or so later, Bobby again journeyed by steamer to Port Albert, selling a pair of new blankets the Board had provided him and once ashore alleging they had been stolen, and then taking another steamer to Ramahyuck. After only a few days he found once more that he could not 'agree with the other blacks' (as he later expressed it) and left, hoping to get back to Port Albert but the steamer captain - who was on good terms with Hagenauer - refused to take him. ${ }^{36}$

Bobby stayed in the district apparently, but in late August he was arrested in Sale as a vagrant, cautioned and discharged on the condition he go to Ramahyuck. It soon became apparent he was deeply distressed; while he was treated compassionately by Aborigines and the missionaries at Ramahyuck, he believed that he was being poisoned. His behaviour suggests he was suffering acute paranoia, although this psychological condition clearly owed something to his continuing belief in sorcery. Hagenauer mounted a 'strict watch' on him but late one evening Bobby slipped away from the station, and even though Hagenauer informed the police and sent some men out into the bush to look for him Bobby eluded them and made his way back to Melbourne and Coranderrk. ${ }^{37}$

By the following February he had again shown a desire to return to Gippsland, and in early April he arrived at Ramahyuck and was taken in by an Aboriginal couple John and Emily Ellis. He shared their cottage and food for a few days, but then moved out and took shelter under a bark mia-mia. He declared the Ellis's cottage to be 'poisoned' and refused to take food from anybody, claiming it too was poisoned. On April 12 he went off Ramahyuck after telling Hagenauer he wanted to buy bread which 'would not have any poison in it'; he returned to the station later but then left again, moving around the neighbourhood for about a week, begging at stations. (At one station where his requests for food were rejected Bobby angrily told a passer-by 'he would not remain there because he could not get anything to eat'.) Eventually he was tracked down by Hagenauer, but Bobby adamantly refused to go back to Ramahyuck or to the Sale hospital 'to starve or die', as he believed he would be poisoned at either place. He could not stay out of the clutches of the missionary, however, and was arrested on a charge of vagrancy. On April 27 he appeared in court where the magistrate, Mr W.H. Foster, decided it would be useless to send him back to Ramahyuck and so remanded him for a week whilst he awaited instructions from the Board. Out of court the coroner, Arbuckle, declared Bobby was insane.

By then the matter had already taken on another dimension as on April 20 the Argus had published a letter by the overseer of the pastoral station near Ramahyuck where Bobby had gone on the twelfth, which told of a blind Aboriginal man being denied food and shelter by Hagenauer and forced off the station because he refused to do any work. The following week both local newspapers reported the case from the metropolitan source, noting it was

36 John Green to Secretary, BPA, 20, 26 February 1873 (AA Brighton, Series B313, Item 163); BPA, Minutes, 7 March 1873 (AA Brighton, Series B314, Item 3); Gippsland Mercury, 27 April 1874; Gippsland Times, 28 April 1874.

37 Gippsland Times, 26 August 1873,28 April 1874; Gippsland Mercury, 27 April 1874. 
'a very grave charge indeed'; Hagenauer also refuted the allegations in letters to the Argus and the local newspapers. A few days later another settler savagely attacked Hagenauer in the columns of the Gippsland Times for 'a glaring case of inhumanity to a wretched black on the part of one who is supposed to be, and who certainly ought to be, the friend and protector of the Aborigines'; in the same edition, one of the newspaper's correspondents claimed parts of Bobby's story were exaggerated, but argued there was sufficient truth in it to justify an inquiry 'with the view of ascertaining how the mission station is really managed' for 'the fact ... seems undeniable that he has neglected the duty which it was his Christian office to have discharged by properly caring for the poor blackfellow at the mission station'.

These allegations and the unfavourable publicity upset both Smyth and Hagenauer, and the two strong-willed and headstrong men angrily disagreed over what action should be taken. Smyth demanded an explanation and accused the missionary of neglecting his duty. Hagenauer had not refused Bobby food, clothes or shelter, but he undoubtedly saw him as a threat to the mission station and certainly wanted to get him removed. He responded to Smyth's criticism by telling him it was 'well known' that Bobby was 'silly' and 'often out of his mind', and argued that he was 'unmanageable' and could not be compelled to stay on Ramahyuck or any other station; 'it would be very desirable for the sake of himself and public justice, if he could be placed in an institution for such people', he suggested. Smyth took umbrage at Hagenauer's recommended course of action, claiming the missionary had 'usurped a power [to determine residence of an Aborigine] that can be exercised only by the Government'. The Board, however, sided with Hagenauer and recommended Bobby be sent back to Melbourne. In early May Bobby appeared in court in Sale, where he was remanded further and handed over to the police who transferred him to Melbourne a few days later. ${ }^{38}$

It seems that the Board had decided Bobby was insane and should be confined to a mental asylum and immediately set in train the procedures for committal stipulated by the colony's 1867 Lunacy Statute. ${ }^{39}$ Within days of his arrival in Melbourne, the Board asked the Government Chief Medical Officer and a general practitioner to examine Bobby, who was in the custody of the police, believing they would either decide that Bobby was insane or at the very least rule that he was a proper person to be detained in a mental institution - the Act construed insane as 'any person ... found ... idiot lunatic or [to be] of unsound mind and incapable of managing himself or his affairs'. Both doctors, however, refused to perform the role they were so often called upon to play, legitimising a decision by another party that an alleged lunatic was insane; between them, they decided that Bobby was suffering from hepatitis, lumbago, gastric problems and blindness, but neither concluded that he was insane. The Chief Medical Officer decided he was merely irritable because of his detention, and recommended he should be allowed to return to his own country; the other doctor suggested that Bobby be cared for on one of the mission stations. ${ }^{40}$ They advised the justices or magis-

38 Argus, 20 April 1874:5; Gippsland Mercury, 20, 24, 27 April 1974; Gippsland Times, 21, 25, 28 April, 2, 5, 9 May 1874; Hagenauer to Secretary, BPA, 23, 27, 28 April, 1,6 May 1874, Mr W.H. Foster to Secretary, BPA, 4 May 1874 (AA Brighton, Series B313, Item 164); Secretary, BPA to Hagenauer, 20, 27, 29 April 1874 (AA Brighton Series B329, Item 2).

3931 Victoria, no. 309.

40 Dr Gibson to Secretary, BPA, 16 May 1874, Chief Medical Officer to Secretary, BPA, 19 May 1874 (AA Brighton, Series B313, Item 164). 
trates considering the case accordingly, but the Board apparently persuaded them otherwise, and Bobby was committed.

At this time, it was relatively easy to get people admitted to mental asylums; among the confined were not only inmates who were insane but also those whose insanity was questionable, or merely a nuisance to their families or to society at large, and dependents who had no one to look after them. Victoria at this time lacked a sufficient number of other institutions, such as benevolent asylums, to house the poor and the helpless, ${ }^{41}$ and the mission stations were not yet regarded as places for dumping aged and ill Aborigines, but as potentially viable economic units.

It is possible that Tarra Bobby was suffering from the terminal form of syphilis, but the understanding that this could cause insanity only emerged clearly late in the nineteenth century. For much of this period, lunacy was linked to immoral behaviour rather than directly to any physiological causes; the most salient symptom of insanity was thought to be a failure or perversion of moral sense, and it was believed it could be brought on by 'intemperate habits'. By this criterion many 'tribal Aborigines' were at risk of being considered 'insane' by the missionaries, and several other traditionally-oriented Aboriginal men were to follow Tarra Bobby to mental asylums in Victoria after they had been labelled as dangerous troublemakers or 'restless wanderers' who had inexplicably rejected 'the comforts of civilised life' on the mission stations. ${ }^{42}$

When the necessary procedures were completed, the police took Bobby to Kew Mental Asylum, a 320 acre reserve on the Yarra River. Perhaps it was just as well Bobby was practically blind, for he could not see the world he was leaving and the one he was entering; had he turned around before crossing the threshold of the institution he would have looked over the Yarra Valley, which had become very familiar territory to him and towards the mountains through which he had passed so many times on his way to Brataualung territory. Ahead lay the imposing facade of the asylum, its buildings looking more like a gaol than a hospi$\mathrm{tal}^{43}$ On entering, Bobby was placed in 'the receiving ward' where he would have been sedated while the medical officers studied his case before classifying him as suffering from delusionary insanity and drafting him into a ward. ${ }^{44}$

The asylum was like a gaol or a workhouse, and its inmates were regarded and treated as prisoners 'to be watched, guarded and fed'. 45 With its confined sense of time and space, it constituted a nightmarish institutional world which Bobby had spent much of his life avoiding and here, unlike the mission stations, there was no chance of escape short of death. There were no procedures for allowing those in an enfeebled state of health to be transferred to another institution, and it was virtually impossible to get round the surveillance of the warders. ${ }^{46}$ Not surprisingly, very shortly after his admittance, Bobby's anxiety began to take

41 James 1877:95-97; Foster 1981:103.

42 Gippsland Times, 16 October, 18 November 1875; BPA, 12th Report 1876:32; BPA, 17th Report:15; Bulmer Papers, Paper 7; Bulmer to Howitt (Howitt Papers (a), 1053/3a); Showalter 1987:111.

43 James 1877:79, 159; Foster 1981:105.

44 James 1877:121-22; Case Records, Tarra Bobby (Kew Asylum Records).

45 James 1877:140-41, 158-89, 162, 182-83.

46 James 1877:96; Report of the inspector of asylums 1870:4. 
its toll on his weak constitution. Perhaps once more feeling that he was being poisoned and continuing to associate illness with location, he began vomiting his food. He was transferred to the hospital where an unspecified abdominal disease was diagnosed and medical aid was administered; his condition, however, continued to deteriorate, and on 7 June he died, little more than two weeks after his admission. ${ }^{47}$

In many respects Tarra Bobby's life was respresentative of the experience of many Aboriginal men in colonial Australia. Born into a community which was suffering the effects of loss of tribal land, disease and conflict and yet curious about European society, Bobby had grown up in two strikingly different milieu. He had developed a strong allegiance to traditional Aboriginal beliefs and his own country, and he played an important role as messenger within that tribal world. But European culture also drew him not only as a provider of material goods but also as a source of different social and cultural mores, and for a time he acted as a mediator between that society and his own. Yet his attraction to European society also had serious and unforeseen consequences, for it tended to bring Bobby into direct conflict with aggressive whites as well as the 'white man's laws' (to the point of his nearly losing his life). Initially this did not blight his enthusiasm for European society, and he eagerly embraced what he saw as the potential in Aborigines 'sitting down' on reserves. Before very long, however, he became disillusioned with these, rejecting paternalistic missionary control and becoming alienated from those Aborigines who seemingly embraced missionary teachings and mode of life. Coincidentally, though, his own tribal world disintegrated beyond the point in which it could sustain him in any meaningful social and economic way. In this situation of growing powerlessness, Bobby adopted a variety of strategies for surviving. They ranged from an escape into alcoholic oblivion at one extreme to a turning back to his traditional religious world on the other. Just as importantly, he learned how to exploit those with power and authority, in particular government officials and missionaries, manipulating them to his own advantage. But this in turn caused considerable conflict with these agents of colonialism as they tried to suppress traditional cultural expressions and any other behaviour deemed to be disruptive of their regimes. They came to see and label Bobby as 'mad' rather than merely 'bad'. In choosing to live off Aboriginal missions Bobby needed both a community of like-minded Aborigines and sympathetic Europeans in order to survive. As the years went by, however, he became more isolated and alone, particularly after the death of the kindly Guardian of the Aborigines, William Thomas. Likewise, his health suffered as years of peripatetic movement, alcohol abuse and poor diet diminished his vitality. As his ability to elude or outmanoeuvre missionaries and government bureaucrats was lessened, Bobby became more and more vulnerable to their control. Not surprisingly they eventually succeeded in incarcerating him in an institution similar to that which he had experienced as a young man and which bore some of the characteristics of those mission stations Bobby could never abide.

47 Case Records, Tarra Bobby (Kew Asylum Records). 


\section{BIBLIOGRAPHY}

Aborigines, Return to an address, Mr Parker - 21st October 1853. Victoria, Legislative Council, Votes and Proceedings, 1853-54, vol.2.

Attwood, B.M. "“. . In the name of all my coloured brethren and sisters": a biography of Bessy Cameron', Hecate 12 (i/ii), 1986:9-53.

The making of the Aborigines. Forthcoming monograph.

Australian Archives, Brighton, Series B312, B313, B314, B329.

Aveling, Marian. 'Nanny: daughter of the Pangerang', in Marilyn Lake and Farley Kelly.eds, Double time: women in Victoria - 150 years. Ringwood, 1985.

Barwick, Diane. 'Rebellion at Coranderrk', seminar paper, Research School of Pacific Studies, The Australian National University, 1968, Australian Institute of Aboriginal Studies, MS 1669.

'Writing Aboriginal history: comment on a book and its reviewers', Canberra Anthropology, 4(2):

74-86, October 1981.

_- 'Mapping the past: an atlas of Victorian clans 1835-1904', Aboriginal History, 8(2):100-31, 1984. " "This most resolute lady": a biographical puzzle resolved', in Diane Barwick, Jeremy Beckett and Marie Reay eds, Metaphors of interpretation: essays in honour of W.E.H. Stanner. Sydney, 1985.

Beckett, Jeremy, 'George Dutton's country: portrait of an Aboriginal drover', Aboriginal History, 2(1): 2-31, 1978 .

Board for the Protection of the Aborigines (BPA), formerly Central Board to watch over the interests of the Aborigines, Annual Reports Australian Archives, Brighton, Series B332 (also published in Victorian Parliamentary Papers).

Bride, Thomas (comp). Letters from Victorian pioneers. First published 1898. Melbourne, 1969.

Brodribb, William Adam. Recollections of an Australian squatter 1835-1883. First published 1883. Sydney, 1978.

Buckley, Patrick Coady. Journal, 1844-53, 1862-72. La Trobe Library, State Library of Victoria, MS 6109; 1854-62, Port Albert Maritime Museum.

Bulmer, John. Papers. Museum of Victoria, Box 11, Folder 1.

Case records of Kew Mental Asylum. Mental Health Commission, Victoria.

Central Board to watch over the interests of the Aborigines (CBPA). See Board for the Protection of the Aborigines.

Committee on Immigration Report. New South Wales, Legislative Council, Votes and Proceedings, 1842.

Fison, Lorimer and A.W. Howitt. Kamilaroi and Kurnai. London, 1880.

Foster, Stephen. 'Imperfect Victorians: insanity in Victoria in 1888', Australia 1888, 8:97-116, Sep tember 1981.

Hagenauer, F.A. Letterbook 1865-72. National Library of Australia, MS 3343.

Harrison, Bessie. 'The making of a town'. Royal Historical Society of Victoria, MS 4814.

Howitt, A.W. Papers (a). La Trobe Library, State Library of Victoria, MS 9356. Papers (b). Museum of Victoria, Box 1, Folder 6.

'On the migration of the Kurnai ancestors', Journal of the Anthropological Institute of Great Britain and Ireland, 15:409-22, 1886.

'On gome Australlan medicine men, or doctors and wizards of some Australian tribes', Journal of the Anthropological Institute of Great Britain and Ireland, 16:25-59, 1887.

The native tribes of south-east Australia. London, 1904.

James, John Stanley. The Vagabond papers. Melbourne, 1877.

Kennedy, Marnie. Born a half caste. Canberra, 1985.

King, John. Daybooks, $1844-46,1848-49,1854-63$. La Trobe Library, State Library of Victoria, MS 11396.

Leslie, John and Helen C. Cowie eds, The wind still blows. Sale, 1973.

Mackaness, George ed. George Augustus Robinson's journey in south eastern Australia 1844. Sydney, 1941.

Mathews, Janet. The two worlds of Jimmie Barker: the life of an Aboriginal 1900-1972. Canberra, 1977.

Moravian Mission in Australia. Papers, Correspondence, Transactions, Diaries and Related Material. Australian Institute of Aboriginal Studies, MF 166.

New South Wales Archives Office, Series 4/1141.2.

Pedersen, Howard. "'Pigeon": an Australian Aboriginal rebel', Studies in Western Australian History, 8:7-15, December 1984.184.

Penny, Jan. 'Queen Aggie: the last of her tribe', in Marilyn Lake and Farley Kelly eds, Double time: women in Victoria - 150 years. Ringwood, 1985.

Public Record Office of Victoria, Series 19, 30, and 2896. 
Report of the inspector of asylums on the hospitals for the insane for 1870. Victoria, Legislative Assembly, Votes and Proceedings, 1871, vol.2.

Robinson, George Augustus. Journal, 1844. La Trobe Library, State Library of Victoria, MS 9974.

Roughsey, Dick. Moon and rainbow: the autobiography of an Aboriginal. Sydney, 1971.

Roughsey, Elsie. An Aboriginal mother speaks of the old and the new. Fitzroy, 1984.

Select Committee on the Aborigines. New Sou th Wales, Legislative Council, Votes and Proceedings, 1845.

Select Committee on the Aborigines. Victoria, Legislative Council, Votes and Proceedings, 1858-59.

Shaw, Bruce. My country of the pelican dreaming: the life of an Australian Aborigine of the Gadjerong, Grant Ngabidj, 1904-1977. Canberra, 1981.

Banggaiyerri: the story of Jack Sullivan. Canberra, 1983.

Countrymen: the life histories of four Aboriginal men. Canberra, 1986.

Showalter, Elaine. 'On the borderland: Henry Maudsley and psychiatric Darwinism', in Elaine Showalter ed., The female malady: women, madness, and English culture, 1830-1980. London, 1987.

Smyth, Robert Brough. The Aborigines of Victoria, vol. 1. Melbourne, 1878.

Thomas, William. Papers. Mitchell Library, uncatalogued mss, set 214, Items 4, 5, 7, 16 and 17.

Tindale, Norman B. Aboriginal tribes of Australia. Canberra, 1974.

Tucker, Margaret. If everyone cared. Sy dney, 1975.

Tyers, Charles J. Diaries etc. 1839-63. La Trobe Library, State Library of Victoria, MS 8151.

West, Ida. Pride against prejudice: reminiscences of a Tasmanian Aborigine. Canberra, 1984.

White, Isobel, Diane Barwick and Betty Meehan eds., Fighters and singers: the lives of some Australian Aboriginal women. Sydney, 1985.

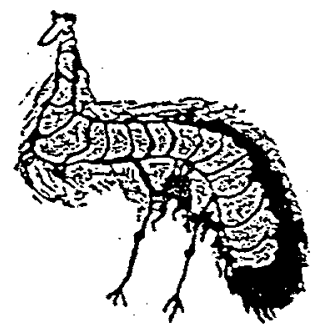

